\title{
Exploration and Research on Internet Plus Education in Cloud Experiment Teaching of Colleges and Universities
}

\author{
Zhicao $\mathrm{Xu}^{1}$, Yu Cao ${ }^{2}$, Ren Song ${ }^{1}$, Yang $\mathrm{Li}^{1,}{ }^{*}$ \\ ${ }^{1}$ Jilin University of Finance and Economics, Changchun, Jilin Province, China \\ ${ }^{2}$ Harbin University of Finance, Harbin, Heilongjiang Province, China \\ *Corresponding author
}

Keywords: Virtual Simulation Technology, Cloud Laboratory, Cloud Technology, Personnel Training, Teaching Reform, Computer Technology.

Abstract. This paper focuses on "Internet plus education" in cloud experiment teaching. It tries to solve problems encountered by universities and colleges in cloud experiment teaching, such as how to improve teaching quality, how to reduce laboratory maintenance cost, and how to share teaching resources. Universities can use Internet technology to construct cloud desktop, and use virtual simulation technology to build cloud laboratory, which marks a great substantial leap in the development of cloud experiment teaching. This teaching mode breaks the traditional mode of teaching and learning, enhances students' learning interests, promotes the educational system reform, and contributes greatly to the cultivation of useful talents for our country.

\section{Introduction}

Education is a part of human society. It appears with the emergence of human society, and develops with the progress of human society. Since the slave society, the development of education has maintained a necessary relationship with the development of human society. However, the development of education generally lags behind the society, since it is restricted by social development, especially the development of advanced productive forces, as well as the development of science and technology. The development of advanced productive forces is not only the decisive force of human society, but also the decisive force in education.

The history of twentieth century also proves the influence of social development, as well as the scientific and technological revolution on educational reform. In the late twentieth century and early nineteenth century, both the "progressivism" education reform and the new education movement were influenced by industrial revolution. The educational reform in 1950-1970 was impacted by the revolution of science and technology. The tide of educational reform since 1980s is also the product of modern scientific and technological revolution. Nowadays, the new information technology revolution marked by network technology also has direct impacts on educational reform. [1]

Now, in colleges and universities, "Internet plus education" mode can make the cloud experiment teaching system develop steadily, which will make a qualitative leap in the development of education. It will not only promote the reform of education system, but also promote the social progress of China.

The Necessity of "Internet Plus Education" in Cloud Experiment Teaching of Colleges and Universities

With the development of economy and society, as well as the progress of science and technology, our country wants to step into the stage of developed countries. Enterprises now have greater demands on T type talents with professional knowledge and skills. Thus, social demands on college graduates are also increasing. In college, due to the limitation of time and space, it is difficult to share 
learning materials and teaching resources among teachers and students. Most students cannot find relevant professional information; some they do not know how to use these materials even when they find them. The theory they learned in class is divorced from practice.

For all universities and colleges, experiment teaching is a crucial link in the learning process of students. However, due to various reasons, students hardly operate the real experiment or learn the core content of the experiment. As a consequence, students' learning enthusiasm is not high; they cannot apply their knowledge in experiments. Therefore, experiment teaching in colleges and universities is a problem demanding prompt solution.

To resolve a series of problems, educational reform is an inevitable choice. This paper focuses on "Internet plus education" in cloud experiment teaching. It tries to solve problems encountered by universities and colleges in cloud experiment teaching, such as how to improve teaching quality, how to reduce laboratory maintenance cost, and how to share teaching resources.

\section{The Main Content of "Internet Plus Education" in Cloud Experiment Teaching of Colleges and Universities}

With the continuous development of Internet in the field of education, high-quality educational resources have been greatly enriched. Rich learning resources can evoke the enthusiasm and desire of students. The cloud laboratory also uses Internet as a big platform, adopts automation and process management methods. In this way, advanced information technology can be expanded, the sharing of experimental resources can be realized, students' learning interests can be stimulated, and the teaching quality of colleges and universities can be improved.

Professor Mao-yuan Pan, a famous Chinese scholar of higher education, believes, "a modern specialized personnel must have the following knowledge structure: first, widened basic knowledge; second, deepened professional knowledge; third, general frontier knowledge, which means the dynamic trend of specialized disciplines, or the new and important achievements and problems in science; fourth, necessary fundamental knowledge on cross discipline and science methodology; fifth, general basic cultural knowledge, or knowledge which is not related to major they studied, but is conducive to broaden their horizons, develop their thinking and improve their cultural accomplishment. To sum up, it is necessary to deal with the relationship between 'broad' and 'deep', and achieve mastery through a comprehensive study." [2]

"Internet plus" refers to a set of information technology based on the Internet, including mobile Internet, cloud computing, big data technology and so on. "Internet plus" is the representative of advanced productive forces, and the practical application results of interne thinking. "Internet plus education" means to apply Internet technology to educational field, promote the development of education, as well as the development of national economy and the society. The biggest advantages of "Internet plus education" experiment teaching in colleges and universities are the reduction of infrastructure cost, and the timely processing of information; the biggest features are global open and transparent communication.

Cloud computing is a new computing and storage model. It manages a great deal of resources, and services for all walks of life. The application of cloud computing in the education industry provides a basic framework on education management, and sets up a virtual digital information platform for education institutions.

Cloud desktop technology means, in the data center of back-end server, different cloud desktop environments are customized according to the requirements of laboratory. Each cloud desktop environment has its own independent hardware performance and software system. As long as there is a network and a display screen, people can access and see the cloud desktop. Students can study at anytime and anyplace. This is helpful to carry out network classroom.

The establishment of cloud desktop environment in colleges and universities provides a virtual experimental environment for experiment teaching; it can solve problems in the experiment teaching like the lack of practical operations, and can meet the requirements of different majors. The establishment of cloud desktop environment in colleges and universities also provides a broad learning environment for students, provokes students' learning enthusiasm; teachers and students can 
use teaching resources effectively. The establishment of cloud desktop environment provides a system with multiple terminals and environments for colleges and universities, reducing the maintenance cost of university laboratories and equipment, and saving resources for schools.

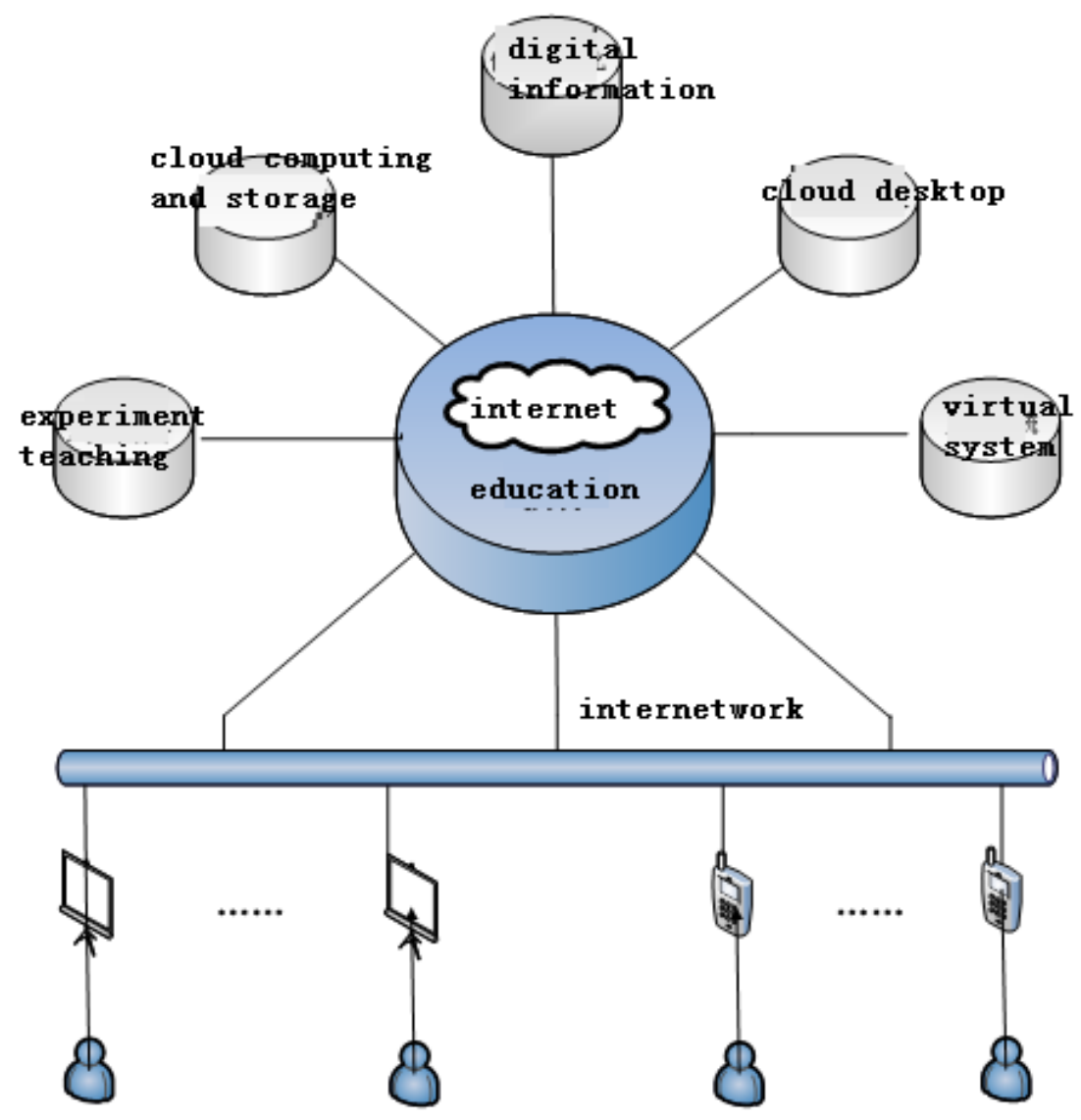

Fig. 1 Mode of "Internet plus education" in cloud experiment teaching

In the future, "Internet plus education" mode will be more widely used in colleges and universities, since it breaks the traditional education mode which is confined to classrooms and schools. Under this new mode, corresponding teaching concept can not only improve the quality of teaching in colleges and universities, but also stimulate students' interests in learning, and plays a positive role in the talents training program of China. Therefore, the research of "Internet plus education" in cloud experiment teaching is of immeasurable value.

\section{The Expected Results of "Internet Plus Education" in Cloud Experiment Teaching of Colleges and Universities}

With the progress of science and technology, as well as the development of society, Internet technology is integrating with all walks of life, and activating the development potential of them. "Internet plus" in education is not a simple superposition. The new form of Internet is developed under innovation 2.0; innovation 2.0 will make this superposition play a more obvious role. When traditional education meets innovation 2.0, education will be forced to change, and the change is first reflected in education concepts. [3] In our country, the education concepts should pay more attention to people and the application of knowledge. Teachers and students should break traditional teaching rules, and change their roles constantly. New science and technology fruits should be used in teaching process; students need to accept knowledge actively, and cultivate a wide range of hobbies.

The Internet is not just a platform; it is also a tool with rich and colorful content. The implementation of the "Internet plus education" in cloud experiment teaching must follow the following principles.

Share the teaching content of cloud experiment. Cloud experiment teaching information of colleges and universities should be seen on the Internet to realize the sharing of high-quality 
educational resources. In higher education institutions, learning resource sharing is very important. Teachers' teaching process and students' learning process are the main method of information communication. The sharing of teaching resources can help students to learn interesting knowledge; teachers can help students according to their own interests, so as to achieve the purpose of teaching and learning.

Maximize the teaching content of cloud experiment. Cloud experiment teaching information in universities and colleges should be good and diversified enough to meet different needs of learners at all levels. In universities and colleges, students want to learn professional knowledge of their majors as deep as possible, and have a little understanding on knowledge about other majors. Therefore, students of different majors have different demands on knowledge.

The rapid development of "Internet plus education" has brought opportunities and challenges to the education industry of China; the rapid development of "Internet plus education" shows the education industry of China is moving towards the big data era. The experiment teaching platform of "Internet plus education" has been built in some colleges and universities to realize the digitization of teaching contents and the randomization of teaching modes. These platforms play a catalytic role in the education reform of China. Therefore, the construction of "Internet plus education" platform in cloud experiment teaching has become a hot issue in the field of higher education research.

\section{The Value and Significance of "Internet Plus Education" in Cloud Experiment Teaching of Colleges and Universities}

With the development of network technology and the reform of higher education, laboratories of universities in our country are constantly increasing. The emergence of cloud technology has made a qualitative leap for the construction and development of university laboratories. In colleges and universities, the Internet has realized the high-speed transmission of data and information, and has changed the original form of education. A school, a classroom, a teacher and more than 100 students: this is traditional education. A special education Internet, a mobile internet terminal, millions of students, optional schools and teachers: this is the "Internet plus education".

The exploration and application of "Internet plus education" in cloud experiment teaching is of great value. Through the establishment of servers and cloud desktop virtual environment, the running of multiple virtual systems in each server, and the operating and application of software installed in the virtual system, colleges and universities can construct a flexible and reliable cloud experiment teaching environment. From the perspective of experiment teaching, this method can provide a cloud experiment teaching environment for teachers and students, improve the utilization rate of experimental resources, realize the sharing of learning resources, and effectively solve the problems of software upgrading, high maintenance cost, the lack of process management and quality control. "Internet plus education" in cloud experiment teaching effectively improves the quality and level of experiment teaching, stimulate students' interests in learning, and lay the foundation for cultivating inter-disciplinary talents.

At the Third Session of the Eleventh National People's Congress in 2015, Premier Ke-qiang Li put forwards the "Internet plus" action plan, which means to use the new generation of information technology, which is represented by big data, cloud computing and artificial intelligence, to support educational informatization and optimize educational resources, promote innovations in education and teaching mode, and the reform of education concepts.[4] The Internet is a tool for public entrepreneurship and innovation. "Internet plus education" in cloud experiment teaching provide opportunities to both entrepreneurs and employees, and has far-reaching significance to the field of education.

\section{Acknowledgements}

Fund Project: This paper is one of the outcomes of the research, Construction of Comprehensive and Interdisciplinary Simulated Practice Training Platform in Universities of Finance, which is supported by Foundation for Scientific and Technological Projects of The Thirteenth Five-Year Plan of Jilin 
Provincial Department of Education (Contract No: JJKH20170122KJ), and the research Localization Mode of Cultivating Innovative and International Talents in Colleges and Universities in Jilin Province, which is supported by Foundation for Educational Programming Projects of Jilin Province (Contract No: GH150278).

\section{References}

[1] L. Sun, M. Li, Higher education reform under the background of "Internet plus", J. China Management Informatization. 11 (2017).

[2] W. Shen, Y.N. Li, Construction of compound undergraduate talents training mode in colleges and universities, J. Journal of Shenyang Normal University: Social Science Edition. 03 (2008) 89-91.

[3] Q.F. Wang, X.Y. Cao, L. Lu, Analysis on the development of "Internet plus" education, J. The Chinese Journal of ICT in Education. 15 (2015) 9-11.

[4] "Internet plus" activates more information energy. Internet of Things in China. [Date of quote: July $\left.1^{\text {st }}, 2015\right]$ 